UDC $004.82+004.91+005.94$

Oleksandr Y. Stryzhak ${ }^{1}$, Doctor Habilitat (computer science), Supervisor Scientist ORCID ID 0000-0002-4954-3650 e-mail: sae953@gmail.com

Hrihorii M. Potapov ${ }^{1}, \mathrm{PhD}$ (computer science), Senior Scientist ORCID ID 0000-0002-5778-9327 e-mail:pgm201602@gmail.com

Vitalii V. Prychodniuk ${ }^{1}, \mathrm{PhD}$ (computer science), Junior Scientist ORCID ID 0000-0002-2108-7091 e-mail: tangens91@gmail.com

Roman I. Chepkov ${ }^{2}$, advisor to the director

ORCID 0000-0003-2810-4576 e-mail: chepkovroman@ukr.net

${ }^{1}$ Institute for Telecommunications and Global Information Space of NASU, Kyiv, Ukraine

${ }^{2}$ Scientific and Research Institute of Geodesy and Cartography, Kyiv, Ukraine

\title{
EVOLUTION OF MANAGEMENT - FROM SITUATIONAL TO TRANSDISCIPLINARY
}

\begin{abstract}
The article examines the development of management as a system based on the analysis of information resources that determine management processes. The main stages of processing information database management systems - analysis, structuring, synthesis, selection are considered. Methodological apparatus, which is based on metacategory of transdisciplinarity is determined. The definition of the category of transdisciplinarity is also analyzed, its definition is given, its system components are described. Technological solutions for the creation of transdisciplinary systems are suggested. The conditions for the formation of a transdisciplinary display of network information resources as the basis of the control circuit are considered.

Key words: management; transdisciplinarity; efficiency; hyperproperty; recursion; reflection; reduction; ontology
\end{abstract}

\section{О.С. Стрижак ${ }^{1}$, Г.М. Потапов ${ }^{1}$, В.В. Приходнюк ${ }^{1}$, P.I. Чепков ${ }^{2}$}

${ }^{1}$ Інститут телекомунікацій і глобального інформаційного простору НАН України, м. Київ, Україна

${ }^{2}$ Науково-дослідний інститут геодезії і картографії, м. Київ, Україна

\section{ЕВОЛЮЦІЯ УПРАВЛІННЯ - ВІД СИТУАЦЙНОГО ДО ТРАНСДИСЦИПЛІНАРНОГО}

\begin{abstract}
Анотація. У статті розглядається розвиток управління як системи, в основу якої покладено аналіз інформаційних ресурсів, які визначають управлінські процеси. Розглядаються основні етапи обробки інформаційної бази систем управління - аналіз, структуризачія, синтез, вибір. Визначається методологічний апарат, в основі якого лежить метакатегорія трансдисииплінарності. Також дається і аналізується визначення категоріі трансдисциплінарності, описуються ї̈ системні складові. Запропоновані технологічні рімення щодо створення трансдисциплінарних систем. Розглядаються умови формування трансдисииплінарного відображення мережевих інформаційних ресурсів, як основи контуру управління.
\end{abstract}

Ключові слова: управління; трансдисциплінарність; ефективність; гіпервластивість; рекурсія; рефлексія; редукиія; онтологія

(C) O.Y. Stryzhak, H.M. Potapov, V.V. Prychodniuk, R.I. Chepkov, 2019 


\section{Вступ}

Керівництвом міністерств і відомств України 3 метою підвищення ефективності діяльності в сучасних умовах проводиться реформування системи їх управління [1-7]. Здійснюються організаційно-штатні заходи, які спрямовані на зменшення витрат, що пов'язані з утриманням адміністративних структур.

Основними цілями при цьому визначено:

- спрощення та оптимізація процедури прийняття рішення для підвищення оперативності реагування на нові виклики та загрози, що виникають;

- раціональне використання ресурсів, які належать міністерствам та відомствам тощо.

Для досягнення цих цілей необхідне наукове обгрунтування механізму прийняття рішень у системі управління, окремих підсистем управління та уточнення завдань, на вирішення яких спрямовано систему, що створюється. Також при цьому необхідно врахувати результати аналізу еволюції управління, що в останні роки відбувається більш динамічно. Причиною цього $\epsilon$ розвиток засобів, що використовуються під час прийняття рішень для оброблення невпинно зростаючого обсягу інформації, яку необхідно при цьому враховувати.

Під час аналізу еволюції управління, слід зазначити, що основою управління $є$ певна система управлінських категорій, які визначають такі характеристики управлінської діяльності: для чого виконується процес управління; що є причиною виникнення цього процесу; на що цей процес направлений; який вид впливу має вироблятися у процесі управління. Управління здійснюється послідовно та поетапно. Етапами управління зазвичай є: постановка мети впливу; оцінка ситуації; визначення проблеми; вироблення управлінського рішення.

Результати аналізу дозволяють стверджувати, що управління - це завжди цілеспрямована діяльність і кожний процес управління здійснюється для досягнення певної мети. Тому процес управління передбачає, перш за все, постановку мети, заради якої він буде виконуватися. Недостатньо обгрунтована мета робить процес управління неефективним, а іноді й шкідливим для успішної діяльності організації.

Ситуація - стан керованої підсистеми або окремого об'єкта, який оцінюється відносно мети. Вона виникає в процесі управління під впливом зміни характеристик внутрішніх змінних установи (організації) або чинників зовнішнього середовища, в якому працює установа (організація). Ситуація може чинити на організацію або керований конкретний об'єкт позитивний вплив, підвищуючи ефективність, або негативний, зменшуючи іiі.

Численні ситуації, що впливають на організацію, як правило, $є$ взаємопов'язаними. Одна ситуація викликає за собою багато інших. Тому перший процес управління, який виробляє реакцію на вплив ситуації, викликає появу інших процесів управління, а ті, у свою чергу, викликають нові процеси, тим самим створюючи постійні управлінські цикли.

Ситуації в процесі управління створюють проблеми, які мають вирішуватися особами, що приймають рішення. Проблема передбачає 
виявлення основних протиріч між умовами роботи організації, породженими ситуацією, і необхідними умовами для досягнення організацією своєї мети.

Під час вирішення проблеми використовують системний підхід і простого переліку змінних, що викликали конкретну ситуацію та найбільше впливають на успіх організації, недостатньо для вибору кращого рішення. Для цього необхідно встановити взаємозв'язок між даними змінними і виробити комплексну реакцію на усунення небажаних впливів.

Вироблення управлінського рішення є заключним етапом і акумулює в собі вдалі і невдалі сторони попередніх етапів процесу управління й відкидає неефективні напрями діяльності керованих об'єктів або дій посадових осіб. Заключний етап в сучасних умовах безпосередньо залежить від рівня позиціонування на світовому ринку знань. Це підтверджує мережецентрична фаза еволюції, у яку вступив світ і яка функціонально реалізується на засадах трансдисциплінарної взаємодії усіх інформаційних ресурсів і процесів, що утворюють інтерактивну павутину, у середовищі якої забезпечується накопичення наукових i науково-технічних знань та їх інтегроване оброблення, реалізуються комунікації та підтримуються процеси прийняття рішень.

\section{Категорії управління}

На сьогодні теорію управління можна охарактеризувати чотирма категоріями, які визначаються підходами 3 точки зору операціональності об'єктів та процесів управління (рис. 1).

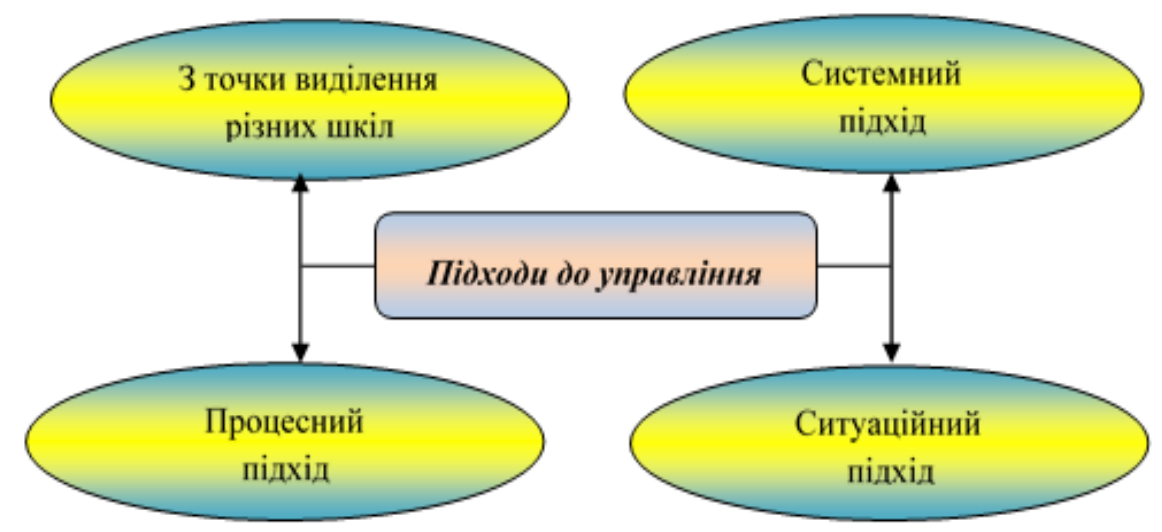

Рис. 1 - Класичні підходи до управління

Підхід з точки зору виділення різних шкіл включає в управління такі напрями: школа наукового й адміністративного управління, людських відносин, науки про поведінку з точки зору кількісних методів $[1,2,6]$.

У системному підходi організація приймається як відкрита система, що складається із сукупності взаємопов'язаних елементів (структури, задачі й технології), функціонування яких спрямовується на досягнення цілей в умовах змінного впливу зовнішнього середовища $[6,7]$.

Вихідним у системному підході є поняття цілі. Наявність конкретної цілі перша і найважливіша ознака організації, за якою дана система відрізняється 
від інших оточуючих іï систем. Завдання управління в цих умовах забезпечити комплексний процес досягнення цілей, що стоять перед системою. Під час використання цього підходу припускають, що кожний 3 елементів системи має певні власні цілі і його сутність полягає в обгрунтуванні напрямів підвищення ефективності роботи організації в цілому.

Особливості системного підходу зводяться до:

- чіткого визначення цілей і встановлення їх ієрархії;

- досягнення найкращих результатів при найменших витратах шляхом використання інструментів порівняльного аналізу i вибору способів досягнення поставлених цілей;

- широкого всебічного оцінювання всіх можливих результатів діяльності 3 використанням кількісної інтерпретації цілей, визначенням методів і засобів їх досягнення.

Таким чином, зазначений підхід орієнтовано на досягнення цілей системи через вибір та реалізацію прийнятих рішень на основі врахування і аналізу всієї сукупності факторів, їх взаємозв'язку та взаємодії, що впливають на необхідність вирішення визначеної проблеми.

Прочесний niдxid розглядає управління як безперервну послідовність взаємопов'язаних управлінських функцій. У ньому приймається функціональний погляд на процес управління, в якому реалізуються такі функції, як планування, організація, мотивація і контроль за прийнятим рішенням. Функції є основою для розподілу управлінської праці, організації процесів управління, формування організаційних структур i, насамкінець, створення функціональних видів управління [2, 3].

Cитуаційний підхід базується на прийнятому припущенні, що використання різних методів управління визначається ситуаціями, на які необхідно реагувати [3-5]. Відповідно до того, що таких ситуацій безліч, припускається, що не існує єдиного оптимального способу управління i найбільш ефективним є метод, який відповідає ситуації, що склалася у даному випадку. Структурну схему концептуальної моделі ситуаційного підходу наведено на рис. 2.

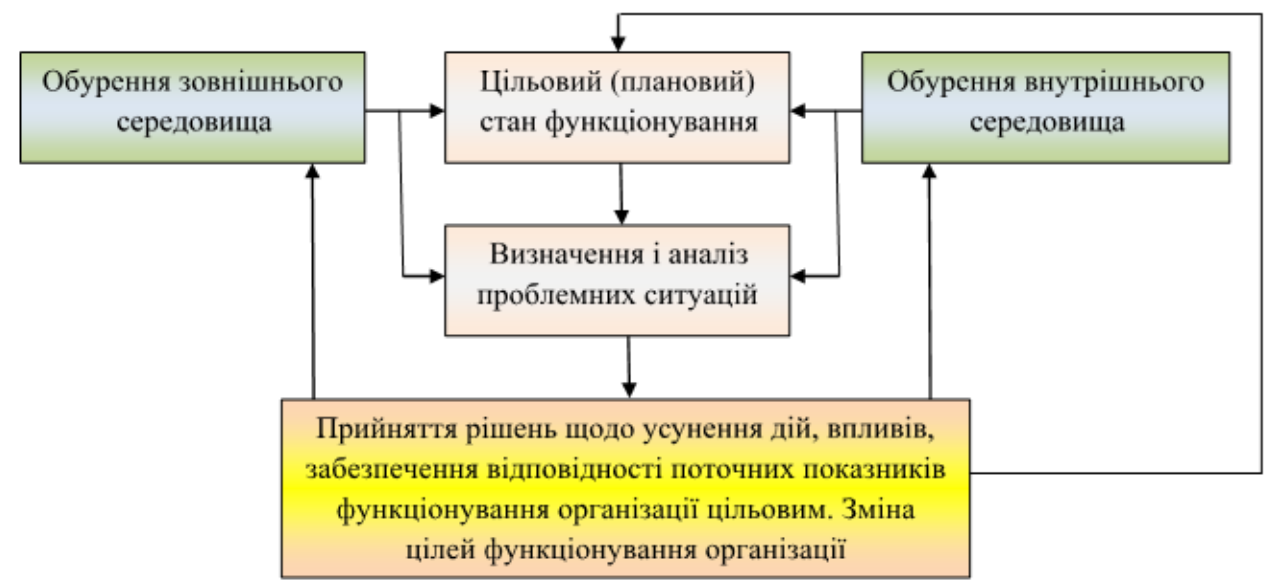

Рис. 2 - Структурна схема концептуальної моделі ситуаційного підходу 
Розвиток динамічності процесів і необхідності оперативного прийняття рішень під час функціонування організації потребує ефективної взаємодії 3 мережевими, міждисциплінарними інформаційними ресурсами, розробки нових методів та засобів управління інформацією для забезпечення доступу до знань, їх об'єднання та формування нових знань. Тому, для більш об'єктивного управління необхідно розглядати відповідні об'єкти та процеси на основі аксіоматик декількох наукових дисциплін, що є найважливішим завданням під час прийняття рішень і потребує розроблення та обгрунтування розподілених мережевих інформаційно-аналітичних систем підтримки прийняття рішень. Потрібно розглядати усю сукупність знань, положення якої відображають різні предметні області. Зазначена система функціонально реалізується на засадах трансдисциплінарної взаємодії усіх інформаційних ресурсів і процесів і формується на основі трансдисциплінарно зв язаних між собою процесів добування, оброблення, зберігання, розповсюдження та використання інформації і знань, які необхідні під час формування рішень.

Відповідно до цього, виникає новий підхід - трансдисциплінарний [8-14], що обумовлює актуальність створення інтелектуальних аналітичних інструментів, які б були спроможні «перебрати» на себе взагалі частину функцій $з$ основного когнітивного тракту людини. Цей підхід забезпечує достовірність та коректність процедури зв'язування тематичних контекстів інформаційних ресурсів глобального середовища на основі множинної впорядкованості [1, 2]. Більше того, усі мережеві інформаційні ресурси являють собою певну сукупність знань, які характеризують їх операціональність $[1,2]$.

Трансдисциплінарність в цьому переліку є замикаючою метакатегорією, яка грунтується на онтологічному представленні формального взаємозв'язку наукових розумінь окремих предметних областей знань (ПдО) та їх функціональної реалізації. При цьому забезпечується формування логічних метарамок, за допомогою яких знання, що відображають тематичні профілі цих предметних областей, можуть бути інтегровані на більш високому рівні абстракції. Трансдисциплінарні онтології забезпечують й реалізують синергію функціональної взаємодії різних предметних областей, включаючи й їх інтеграцію, яка використовується для інформаційно-аналітичного забезпечення підтримки прийняття рішень в контурі управління.

Таким чином, трансдисциплінарний підхід реалізує систематизацію, контекстний та структурний аналіз предметних знань, які відображаються у різних інформаційних ресурсах, забезпечуючи при цьому дослідження інформації.

Слід зазначити, що на процес взаємодії з інформаційними ресурсами глобального середовища впливають такі аспекти:

- синтаксичний, який стосується формальної правильності повідомлень з точки зору синтаксичних правил мови, що використовується, безвідносно до його змісту;

- семантичний, який відображає рівень понятійної взаємодії;

- прагматичний, який визначає операціональні аспекти їх використання.

Трансдисциплінарність інформаційного середовища визначається як множинна часткова впорядкованість таксономічних та операціональних властивостей концептуальних (онтологічних) моделей дисциплінарних метасистем, як певних систем представлення предметних знань. 
При цьому категорія взаємодії з мережевими інформаційними ресурсами глобального середовища може розглядатися як певний процес використання будь-яких контекстів, що їх складають. I на сьогодні найбільш продуктивним та конструктивним $є$ застосування онтологічного підходу [8, 15-20]. Онтологічні методи та системи забезпечують концептуальне відображення взаємодії мережевих інформаційних процесів і систем в різних предметних областях.

Вони містять наступні системні компоненти:

- множину концептів як структуру семантичних одиниць-понять;

- формальну модель предметних знань, представлену за допомогою певної мови на основі опису концептуальної системи;

- функціональну модель, яка забезпечує уніфікацію термінології, логіку обробки таксономічних категорій i відношень між ними, а також аксіоматизацію описів процесів, причинних зв'язків і процедур онтології. В якості онтологічних систем, що різною мірою формалізовані, у літературі розглядаються такі категорії, як: словник 3 визначеннями; таксономія; тезаурус; аксіоматизована теорія тощо.

\section{Концептуальні засади трансдисциплінарного управління}

Трансдисциплінарне використання інформаційних ресурсів реалізується на основі інтерпретації таких гіпервластивостей, як рефлексія, рекурсія та редукція [3, 8, 16, 17, 21-25]. Рефлексивність інформації полягає у іiі спроможності відображати явища, які можна трактувати як знання. Рекурсивність реалізується як здатність постійно використовувати ці знання в операціональному просторі експертів. Редуктивність забезпечує представлення описів явищ через спрощені дефініції.

Вказані гіпервластивості операціонально реалізуються на основі функціональності категорій онтологія та нормальна система [8, 25]. За рахунок цього вказані гіпервластивості інтерпретуються певними функціональними сервісами, які забезпечують когнітивні процедури, до складу яких входять аналіз, структуризація, синтез та вибір. Ці когнітивні процедури досить повно реалізують інтегровану взаємодію з інформаційними ресурсами $[8,17,25]$.

Онтологія $O$ являє собою концептуально-понятійний каркас усіх без виключення наукових теорій. Вона включає понятійну систему предметної області $X$, властивості об'єктів із множини $X-R$, включаючи відношення, які визначають їх взаємодію, та функції $F$, які інтерпретують ці властивості та відношення.

$$
O=\langle X, R, F\rangle
$$

Якщо множину $F$ представити у вигляді $\{$ дія - результати\}, то ми отримаємо клас натуральних систем $S N$, які є певним натуральним покриттям множин $X$ та $R$. Більше того, множина $S N$ визначається множиною можливих наборів узгоджених дій зі множиною очікуваних результатів [25]. Також слід зауважити, що набір можливих дій $F$ може бути визначений за умови, що кожен об'єкт зі множини $X$ визначається певним набором зі множини $R$. 
$S N=(F, X \mid X(R))$.

Виходячи 3 визначень (1) та (2), можна стверджувати, що довільну онтологію можна представити у вигляді натуральної системи та навпаки. Ця двоїстість їх існування визначає гіпервластивість пластичності цих категорій.

За рахунок їх пластичності можливе інтегроване відображення довільного інформаційного ресурсу, який включено у контур управління. Натуральна система $S N$ забезпечує інтегроване відображення набору певних документів, якщо сформована онтологія $O$, яка забезпечує відображення понятійних систем предметних областей, що використовуються. Тоді реалізуються узгоджені дії, які визначають множину результатів взаємодії з документами. Вказані результати являють собою інтерактивний документ $I$, який змістовно являє собою інтегроване представлення частково впорядкованих контекстів усіх документів, що використовуються.

$$
I=\langle O, S N\rangle .
$$

Таким чином, пластичність натуральної системи та онтології забезпечує інтерактивну взаємодію 3 наявною в онтології інформацією у довільному контурі управління. Це, у свою чергу, реалізує формування аналітичних додатків в процесі управління. Аналітичний додаток $A A$ (analytic application) задається на основі функціональних інтерпретацій $F$ властивостей $R$ понятійних систем онтології $O$, що використовується. Сформований на основі інтерактивного документу I аналітичний додаток $A A$ може бути представлений у вигляді (4) [27].

$$
A A=\left\langle X_{g}, R_{g}, A^{o p}, S, O\right\rangle
$$

де $X_{g}$ - множина об'єктних сутностей, над якими виконуються аналітичні операції для вирішення задачі;

$R_{g}$ - множина відношень між об'єктами понятійної системи, які визначають тип виконуваних операцій;

$A^{o p}$ - множина аналітичних операцій над об'єктами, виконуваних в процесі вирішення задачі;

$S$ - множина станів задачі, які використовують зв'язані контексти в процесі іiі вирішення;

$O$ - онтологічний опис об'єктів, процесів і задач заданої предметної області.

Множина аналітичних операцій $A^{\text {op }}$ визначає набір узгоджених дій натуральної системи, до складу якого входять когнітивні операції структуризації; аналізу/виділення проблеми; синтезу та вибору. Варіативність їх використання задається гіпервластивістю рефлексивності $R_{r e f}$, яка включає ці операції до контуру управління та забезпечує знаходження різних рішень і вибір найбільш оптимального $[17,23,25]$. Ця варіативність певним чином залежить, згідно з виразами (2)-(4), від наявності та суттєвості міжконтекстної зв'язності об'єктів, які використовуються у процесі взаємодії. Це визначається вибором аналітичної операції $A^{\text {op }}$ конкретного стану зв'язності контекстів інтерактивного документа $I$. Вказану зв'язність представлено у вигляді виразу (5):

$$
R_{r e f}=\left(A^{o p}, I\right)
$$


Таким чином, рефлексія, представлена виразом (5), визначає умови активізації когнітивних операцій на основі уточнення контекстної значимості та зв'язності об'єктів й процесів управління.

Одним із системних компонентів інтерактивного документа $є$ онтологія. Когнітивні узгоджені операції натуральної системи, як другої системної компоненти інтерактивного документа, забезпечують інтерпретацію гіпервластивостей рекурсія $R_{r e c}$ та редукція $R_{r e d}$. Вказані гіпервідношення утворюють множину $G r$, яку задано над множинними бінарними відношеннями часткової упорядкованості, що визначають таксономічну ієрархію онтологічної системи [21-26].

Інше представлення рефлексії, у вигляді виразу (6), визначає, що кожен контекст понятійної системи онтології є частиною самого себе.

$$
\forall x R(x, x) \rightarrow X G X=X
$$

Це дозволяє уявити певні предикативні вирази, що формуються на основі об'єктів понятійної системи онтології із заданим множинним відношенням часткової упорядкованості у вигляді рекурсивного предиката [21-25]:

$$
\operatorname{Pr}\left(x_{1}, \ldots, x_{n}\right)=\left\{\begin{array}{l}
1, \neg \operatorname{Pr}\left(X G r x_{i}\right) \wedge \operatorname{Pr}\left(x_{1}, \ldots, x_{n}\right) \\
0, \operatorname{Pr}\left(X G r x_{i}\right)
\end{array}\right.
$$

де $x_{i} \in X ; 1 \leq i \leq n, X$ - понятійна система онтології й інтерактивного документа.

Фактично предикат виду (7) дозволяє визначити, які об'єкти онтологічної системи володіють даною властивістю. Сформувавши множину класів об'єктів онтологічної системи за допомогою предикативного виразу виду (7), ми отримуємо таксономію $T$, над якою задано множинне бінарне відношення «частина-ціiле». Така таксономія може мати складну структуру низхідних ієрархій. Кожний складник являє собою клас об'єктів, що мають як мінімум одну загальну семантичну властивість.

$$
\operatorname{Pr}\left(x_{1}, \ldots, x_{n}\right)=0 \Rightarrow \exists T \subseteq \breve{T}: \forall x \in X \exists Y \subseteq X: T=Y G r x
$$

Гіпервідношення $G r$ визначає взаємодію між об'єктами кожної таксономії, виділеної 3 різних класів предметної області. Відповідно до цього, рекурсивний предикат виду (7) дозволяє визначити нові види таксономії онтологічної системи. Особливу роль у формуванні нових таксономій відіграє, крім рекурсивних предикатів, функція вибору. У термінах таксономічних категорій вона має наступний вигляд:

$$
\forall T[\emptyset \notin T \Rightarrow \exists F: T \rightarrow \cup T, \forall T \in \breve{T}(F(T) \in \breve{T}]
$$

Тоді характеристична функція рекурсивного предиката (7) може визначати умови застосовності функції вибору при формуванні множини таксономій онтологічної системи. Якщо значення характеристичної функції дорівнює нулю, то ми виділили множину об'єктів, 3 контекстів яких неможливо сформувати істинні висловлювання, тому вони не володіють жодним 3 бінарних гіпервідношень упорядкованості. В протилежному випадку 
характеристична функція приймає значення 1, а 3 множини контекстів обраних об'єктів формують істинні висловлювання.

Згідно 3 цим, над ними можуть бути визначені гіпервідношення $G r$. Тобто, завжди можна знайти непорожню множину об'єктів онтологічної системи, де існує хоча б один з типів відношень упорядкованості виду і контексти об'єктів, пов'язані таким відношенням, можуть утворювати істинні висловлювання. Таким чином, ця умова задає індуктивність процесу формування множин зв'язних між собою контекстами об'єктів, між якими встановлюються гіпервідношення $G r$, i фактично конструюється таксономія та/або таксономічна категорія. На підставі тверджень, наданих у вигляді (6)-(9), ця умова може бути представлена в наступному вигляді:

$$
\exists P \subseteq G r, \exists p \in P, \forall x \in X \exists Y \subseteq X: Y G r x \Rightarrow \exists T=Y G r x
$$

Індуктивність виразу (10) задається послідовністю застосування предикативного виразу виду (7) i (8) до множини об'єктів онтологічної системи $O$ й послідовного формування множини інтерактивних документів $I$, як системного компоненту контуру управління.

Послідовність виразів (1)-(10) фактично визначають індуктивність формування і рекурсії $R_{\text {rec}}$, як гіпервластивості, що забезпечує міжконтекстну зв'язність об'єктів інтерактивного документа.

Однак повне визначення когнітивних операцій, які оперують контекстами інтерактивного документа, потребує ще визначення редукції, яка забезпечує конвертацію складних представлень міжконтекстних зв'язків об'єктів контуру управління у більш прості вирази.

Таку гіпервластивість, як редукція, та їі функціональну інтерпретацію найбільш конструктивно описувати в термінах $\lambda$-теорії. $\lambda$-теорія $(\lambda$-числення) - формальна теорія, розроблена для формалізації i аналізу поняття обчислюваності [28]. Поняття редукції $\epsilon$ досить конструктивним для представлення взаємодії всіх системних утворюючих онтології в термінах $\lambda$-числення. Системні складові визначаються канонічною формою онтології, і як вже було зазначено вище, це - кількість об'єктів онтології, множина відношень між ними і множина інтерпретуючих функцій. Якщо формувати $\lambda$-вирази за кожною категорією окремо, то ми все одно отримуємо безтипові вирази, які відображають набори певних правил, згідно з якими можуть бути сформульовані розв'язувані твердження.

Основними поняттями $\lambda$-теорії $\epsilon$ аплікація (застосування функції до аргументу) і абстракція. Абстракція означає, що якщо $t(x)$ - вираз, який, можливо, містить в собі вільну змінну $x$, то запис $\lambda x . t(x)$ - це функція $f$, яка ставить у відповідність значенню $a$ значення $t(a)$, інакше кажучи, має місце рівність (11).

$$
(\lambda x . t(x)) a=t(a)
$$

де $x$ - певна змінна;

$t$ - вираз, що містить, можливо, входження змінної $x$;

$a$ - аргумент, що визначає значення $x$.

Центральним елементом $\lambda$-теорії є поняття терму $[23,24,28]$. Множина $\Lambda$ $\lambda$-термів визначається індуктивно, як показано виразом (12): 


$$
\begin{gathered}
\sim 100 \sim \\
x \in \Lambda \\
M \in \Lambda \Rightarrow(\lambda x M) \in \Lambda \\
M, N \in \Lambda \Rightarrow(M N) \in \Lambda
\end{gathered}
$$

де $x$ - довільна змінна;

$M, N$ - довільні терми.

Крім того, в $\lambda$-теорії діє так зване спостереження Штейнфінкеля (13), що дозволяє зводити функції багатьох аргументів до функції одного аргументу [28].

$$
\lambda x_{1} \ldots x_{n} \cdot M=\lambda x_{1}\left(\lambda x_{2}\left(\cdots\left(\lambda x_{n \cdot}(M)\right) \cdots\right)\right),
$$

де $x_{i}$ - довільні змінні;

$M$ - довільний терм.

Важливе значення має поняття $\beta$-редукції, яке можна визначити як відношення (14) між двома термами:

$$
\beta=\{((\lambda x . M) N, M[x:=N]) \mid M, N \in \Lambda\},
$$

де $x$ - довільна змінна;

$M, N$ - довільні терми;

$M[x:=N]-$ вираз, отриманий підстановкою $N$ замість змінної $x$ у виразі $M$.

Поняття редукції в $\lambda$-численні може бути визначено як бінарне відношення $r$ над множиною абстракцій $\lambda$-термів - $\Lambda$ [28]. Редукція $R_{\text {red }}$ має властивості транзитивності, рефлексивності і $є$ бінарним відношенням. Тут слід зазначити, що будь-яка онтологічна система може бути представлена таксономією об'єктів, яка відображає ієрархічні відношення між ними. Причому над таксономією онтології задано множинне відношення часткової упорядкованості $\tilde{p}$. Тобто, ми можемо визначити відношення $\tilde{p}$ як редукцію $R_{r e d}$ на множині абстракцій $\lambda$-термів - $\Lambda$, де терми - суть твердження із контекстів об'єктів онтології, що представлені у вигляді виразів (10)-(14).

Тобто, ми конструюємо математичні вирази, які інтерпретуються смислами i контекстами конкретних тверджень. I проблема полягає в тому, щоб семантично синхронізувати і зв'язати відповідні твердження. При вирішенні зазначеної проблеми ми отримуємо певну повноту інтерпретаційних моделей, представлених у вигляді вирішуваних тверджень. Всі контексти об'єктів, що утворюють ці твердження, обов'язково мають певну ієрархічну підпорядкованість, що утвориться на основі множинного відношення часткової упорядкованості $\tilde{p}$. І ці ієрархічні відношення точно визначають об'єктні класи [29], утворені об'єктами онтології на підставі виділених властивостей і бінарних відношень.

Синхронізація смислів і контекстів всіх тверджень вимагає формування певних правил, які враховують типи їх відношень і властивостей, а також функціональність, яка визначається цими властивостями. Для цього потрібні інструменти, що володіють певною синтаксичною виразністю. Однак, це не відводить нас від проблеми, яку ми вже визначили - семантичної синхронізації контекстів використовуваних типів даних, а тільки ускладнює іiі рішення.

Згідно з вищенаведеним, ми можемо побудувати вирази із $\lambda$-термів, які будуть включати в себе як концепти, так і відношення з функціями. Так як на 
множині цих виразів задається відношення $\tilde{p}$, то ми можемо це відношення визначити як редукцію $R_{r e d}$ на множині абстракцій $\Lambda$. Так як абстракція в $\lambda$-численні трактується як певний засіб конструювання нових функцій 3 виразів виду (11), то можливе формування досить складних функціональних виразів з $\lambda$-термів, які дозволять зв'язати концепти, їх відношення, властивості і функції інтерпретації контекстів концептів онтології.

Тобто, так як редукція $R_{r e d}$ забезпечує підстановку одних виразів в $\lambda$-записи замість інших, то використовуючи вирази виду (11)-(14), ми можемо побудувати пов'язані за значеннями змінних i аргументів розв'язувані $\lambda$-вирази. Ці вирази можуть бути аплікаціями - функціями, застосованими як до конкретних змінних, так i до абстракцій - складних $\lambda$-виразів, які дозволяють пов'язувати контексти конкретних концептів онтологічної системи. При цьому, змінним функцій в $\lambda$-виразі ставляться у відповідність контексти об'єктів онтології, пов'язані між собою $\tilde{p}$ і такі, що беруть участь у конструюванні абстракції як складної функції виду (12)-(14).

В рамках формалізму, прийнятого в $\lambda$-численні [7], описані правила застосування редукції $r$ можуть бути представлені в наступному вигляді:

$$
R_{\text {red }}=\left\{\left(\lambda x . L_{1}\right) L_{2}, L_{3}\left[x:=L_{2}\right]\right\}
$$

де $L_{j} \in \Lambda$, тобто $L_{j}$ являється абстракцією у $\lambda$-виразі вигляду (15).

У зв'язку з цим, весь етап побудови онтологічної системи може бути представлений множиною складних $\lambda$-виразів виглядів (11)-(15). I якщо для декларативного подання онтології достатньо одного з виразів (11)-(14), то іiі активне використання при взаємодії з різними мережевими інформаційними ресурсами вимагає обов'язкового застосування редукції (15).

Таким чином, основною конструктивною перевагою редукції $\epsilon$ iï використання у якості множинного відношення часткової упорядкованості, яке забезпечує поетапне зв'язування концептів на основі врахування їх властивостей i контекстів як функціональних інтерпретаторів ієрархічно пов'язаних об'єктів. Ієрархію, чи точніше таксономію, тепер вже $\lambda$-термів i $\lambda$-виразів визначає редукція множини абстракцій $\Lambda$. Причому між множинним відношенням часткової упорядкованості $\tilde{p}$, заданим на множині об'єктів $X$ онтологічної системи, і редуктором множин абстракцій $\Lambda$ може бути завжди визначено неперервне відображення. Тобто, вся множина детермінованих станів взаємодії онтологічної системи може безперервно відображатися в множину функціональних безтипових виразів, прийнятих в теорії $\lambda$-числення. Таке відображення, крім властивості безперервності, володіє також властивістю оборотності, симетричності, рефлексивності і транзитивності. Тоді відображення між онтологією і їі множиною абстракцій має властивість еквівалентності.

Цікавим є те, що існує відображення з властивістю еквівалентності між структурами, які не можуть мати таку властивість. Ця властивість множинного відношення бінарної упорядкованості дозволяє визначати способи взаємодії між топологічними множинами, що можуть становити функціональні властивості онтологічних систем:

$$
\left(R_{\text {red }} \rightarrow \tilde{p}\right) \Rightarrow((X, R, R u l) \rightarrow \Lambda) .
$$


Вирази (1)-(16) визначають трансдисциплінарність інтерактивного документа як базового системного компонента контуру управління. Вони забезпечують знаходження різних рішень у процесі вирішення задач, що входять у контур управління, на основі інтерпретації властивостей об'єктів онтологічних систем, що взаємодіють. Це фактично відображає людську здатність варіативно мислити.

\section{Технологічні рішення трансдисциплінарного підходу}

Реалізація трансдисціплінарного підходу управління може реалізовуватися на базі когнітивної трансдисциплінарної мережевої технології ІТ-ТОДОС [8, 30-32]. Ця технологія показала ефективність розроблених методів та засобів типізації трансдисциплінарних онтологічних моделей у процесі інтегрованої взаємодії 3 контекстами, які відображають семантичні властивості інформаційних ресурсів глобального середовища. На основі використання моделей відображення впорядкованої множинності семантичних властивостей об'єктів забезпечується трансдисциплінарна інтеграція інформаційних ресурсів на кожному кроці взаємодії з ними.

Програмна система трансдисциплінарного представлення мережевої інформації $є$ системою, призначеною для обробки великих масивів слабко і неструктурованих документів, що можуть бути представлені у вигляді природномовних текстів [16, 30, 32]. Система виконує виділення 3 них інформації за заданими користувачем правилами, іï представлення у вигляді онтологічної структури, а в подальшому - трансдисциплінарне представлення.

Система трансдисциплінарного представлення мережевої інформації призначена для реалізації множини компонентів інформаційної технології структуризації текстів [8, 31, 32], а також розширення множини компонентів інформаційної технології представлення інформації, що реалізується системою ТОДОС.

3 точки зору програмної інженерії програмна система розглядається у вигляді набору описів, які представлені у вигляді математичних моделей, формалізмів і технік моделювання [33, 34].

Структура математичних моделей ПС такого роду включає в себе такі моделі [33, 34]:

1) інформаційна модель;

2) функціонально-компонентна модель.

Інформаційна модель використовується для представлення і опису потоків інформації, структур даних, а також програмних модулів в програмній системі.

Узагальнена інформаційна модель програмної системи трансдисциплінарного представлення мережевої інформації П $R$ має вигляд (17). Вона представляється деякою скінченною сукупністю програмних модулів $\Pi_{R_{i}}$, що інтегруються в інформаційно-аналітичну систему ТОДОС $\Pi_{T}$

$$
\Pi_{R}=\sum_{i=1}^{n} \Pi_{R_{i}} \cup \Pi_{T}
$$


При цьому реалізується відображення $G_{\Pi_{R}}$ інтеграції функцій окремих програмних модулів системи, що має вигляд (18). Дане відображення перетворює об' єднання множини функцій $S_{R_{i}}$ кожного з ії програмних модулів $\Pi_{R_{i}}$ в узагальнену (цільову) функцію $F_{R}$ - трансдисциплінарне представлення мережевої інформації.

$$
G_{\Pi_{R}}: \bigcup_{i=1}^{n} S_{R_{i}} \rightarrow F_{R}
$$

Система ТОДОС, у свою чергу, також має велику кількість багатофункціональних модулів різного призначення. В роботі системи трансдисциплінарного представлення мережевої інформації використовується тільки сукупність $\Pi_{T}^{R} \subset \Pi_{T}$ модулів, що релевантні задачі формування шарів ГІС. Таким чином, формули (17) і (18) перетворюються в (19) і (20).

$$
\begin{gathered}
\Pi_{R}=\sum_{i=1}^{n} \Pi_{R_{i}} \cup \sum_{i=1}^{m} \Pi_{T_{i}}^{R} \\
G_{\Pi_{R}}: \bigcup_{i=1}^{n} S_{R_{i}} \cup \bigcup_{i=1}^{m} S_{T_{i}}^{R} \rightarrow F_{R}
\end{gathered}
$$

Сукупність модулів системи трансдисциплінарного представлення мережевої інформації, що входять до складу базової структури ТОДОС, можна розглядати як окрему підсистему - підсистему структуризації тексту $\Pi_{T X}=\sum_{i=1}^{n} \Pi_{R_{i}}$. Дана сукупність має вигляд (21).

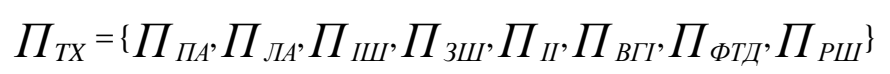

Розглянемо детальніше функції різних модулів підсистеми виділення мережевої інформації з тексту.

$\Pi_{П А}$ - модуль виконання попереднього аналізу вхідного документа. Даний модуль необхідний для приведення документа до текстового формату. Множина функцій даного модуля має вигляд (22):

$$
S_{\Pi A}=<S_{1}^{\Pi A}, S_{2}^{\Pi A}, S_{3}^{\Pi A}, S_{4}^{\Pi A}, S_{5}^{\Pi A}>
$$

До його функцій відносяться:

1) $S_{1}^{\text {ПА }}$ - зчитування вхідного файлу одного з підтримуваних форматів (текст, документи Word, електронні таблиці Excel, файли HTML та ін.);

2) $S_{2}^{\Pi A}$ - отримання текстової інформації, що знаходиться у файлі;

3) $S_{3}^{\text {ПА }}$ - нормалізація кодування отриманої текстової інформації;

4) $S_{4}^{\text {ПА }}$ - виділення і збереження оригінальної розмітки вхідного документа; 
5) $S_{5}^{\text {ПА }}$ - збереження вкладеної в документ мультимедійної інформації (картинок, відео, аудіо та ін.), якщо тип вхідного документа підтримує це. Вихідними даними для даного модуля є текстовий файл.

$\Pi_{Л А}$ - модуль виконання лексичного аналізу (23).

$$
S_{\text {ЛA }}=<S_{1}^{Л A}, S_{2}^{Л A}, S_{3}^{Л A}, S_{4}^{Л A}, S_{5}^{Л A}, S_{6}^{Л A}, S_{7}^{Л A}, S_{8}^{Л A}>
$$

Функції модуля:

1) $S_{1}^{\text {ЛА }}$ - зчитування вхідного текстового файлу;

2) $S_{2}^{\text {ЛА }}$ - розбиття вхідного тексту на речення, а речень - на лексеми (слова і символи);

3) $S_{3}^{\text {ЛА }}$ - нормалізація розбиття у відповідності 3 правилами мови (наприклад, видалення розривів речень, викликаних крапками в складі скорочень і чисел);

4) $S_{4}^{Л A}$ - нормалізація слів;

5) $S_{5}^{\text {ЛА }}$ - визначення частини мови для слів і деяких символів (таких як тире, що замінює певне слово);

6) $S_{6}^{\text {ЛА }}$ - визначення додаткових характеристик лексем;

7) $S_{7}^{\text {ЛА }}$-визначення синтаксичних зв'язків між лексемами;

8) $S_{8}^{\text {ЛА }}$ - формування структур даних первинного представлення тексту.

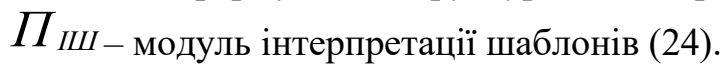

$$
S_{I \amalg}=<S_{1}^{I W}, S_{2}^{I W}, S_{3}^{I W}, S_{4}^{I W I}>
$$

Функції модуля:

1) $S_{1}^{I \amalg I}$ - зчитування файлів шаблонів;

2) $S_{2}^{I Ш}$ - формування внутрішнього представлення для предикатів, 3 яких формуються шаблони;

3) $S_{3}^{I \amalg}$ - формування внутрішнього представлення для шаблонів правил;

4) $S_{4}^{I Ш}-$ формування внутрішнього представлення для правил ідентифікації інформації.

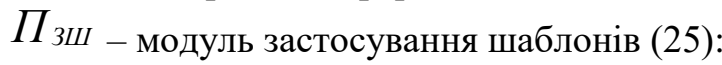

$$
S_{3 W}=<S_{1}^{3 W}, S_{2}^{3 W}, S_{3}^{3 W}, S_{4}^{3 W}>
$$

1) $S_{1}^{3 \amalg}$ - вибірка підпослідовностей лексем з вхідного тексту;

2) $S_{2}^{3 ш}$ - вибірка шаблонів-кандидатів з наявної множини шаблонів; 
3) $S_{3}^{3 Ш}$ - застосування шаблонів-кандидатів до вибраних підпослідовностей лексем;

4) $S_{4}^{3 ш}$ - вибір шаблону, що найкраще відповідає вхідній підпослідовності.

$\Pi_{I I}$ - модуль інтерпретації інформації (26):

$$
S_{I I}=<S_{1}^{I I}, S_{2}^{I I}, S_{3}^{I I}, S_{4}^{I I}>
$$

1) $S_{1}^{I I}$ - вибір застосовної функції інтерпретації інформації;

2) $S_{2}^{I I}$ встановлення відповідності між елементами вхідної підпослідовності, що містить інформацію, і аргументами вибраної функції інтерпретації;

3) $S_{3}^{I I}$ - застосування функції інтерпретації;

4) $S_{4}^{I I}$ - визначення належності отриманої інформації до географічної.

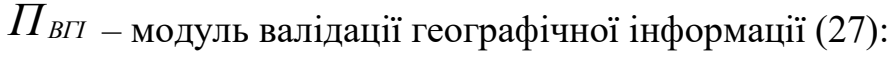

$$
S_{B \Gamma I}=<S_{1}^{B \Gamma I}, S_{2}^{B \Gamma I}, S_{3}^{B \Gamma I}, S_{4}^{B \Gamma I}>
$$

Функції модуля:

1) $S_{1}^{B Г I}$ - визначення коректності всіх частин географічної інформації (наприклад, в географічних координатах значення градусів не повинно перевищувати 180);

2) $S_{2}^{B Г I}$ - нормалізація координат, при необхідності - переведення їх в систему координат WGS-84 [35];

3) $S_{3}^{B Г I}$ - геокодування текстових адрес за допомогою основної або резервних систем геокодування [35];

4) $S_{4}^{B Г I}$ - визначення належності результату до географічної області.

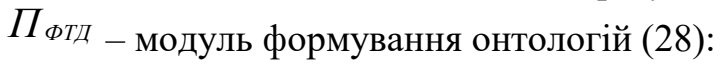

$$
S_{\text {Фтд }}=<S_{1}^{\text {ФТД }}, S_{2}^{\text {ФТД }}, S_{3}^{\text {ФТД }}, S_{4}^{\text {ФТД }}>
$$

Функції модуля:
1) $S_{1}^{\text {ФТД }}$ - нормалізація строкового представлення об'єктів, описаних в тексті;
2) $S_{2}^{\text {ФТД }}$ - формування ієрархії об'єктів згідно 3 наданою текстом інформацією;

 географічну інформацію;

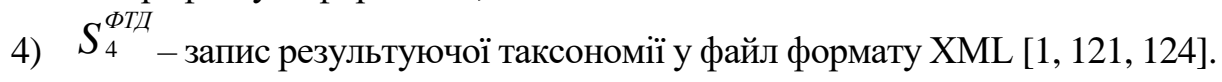




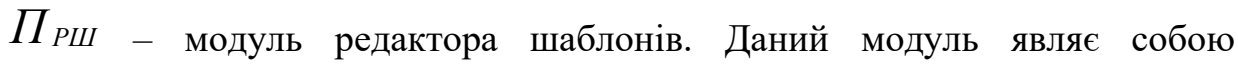
користувацький інтерфейс системи. Він містить в собі набір візуальних редакторів для різноманітних структур даних, що використовуються системою. Множина функцій даного модуля має вигляд (29):

$$
S_{P U}=<S_{1}^{P U I}, S_{2}^{P U I}, S_{3}^{P U I}, S_{4}^{P \amalg I}, S_{5}^{P \amalg I}, S_{6}^{P U I}, S_{7}^{P U I}, S_{8}^{P \amalg I}>
$$

Функції модуля:

1) $S_{1}^{P \amalg}$ - створення і редагування предикатів ідентифікації інформації;

2) $S_{2}^{P \amalg}$ - створення і редагування правил ідентифікації інформації;

3) $S_{3}^{P Ш}$ - встановлення відповідності між правилами ідентифікації інформації і функціями інтерпретації;

4) $S_{4}^{P \amalg}-$ перегляд результатів лексичного аналізу тексту;

5) $S_{5}^{P Ш ~-~ а в т о м а т и з о в а н е ~ с т в о р е н н я ~ п р а в и л ~ і ~ п р е д и к а т і в ~ н а ~ о с н о в і ~}$ результатів лексичного аналізу;

6) $S_{6}^{P \amalg}-$ перегляд результатів роботи системи;

7) $S_{7}^{P \amalg}$-виправлення і уточнення результатів роботи системи;

8) $S_{8}^{P \amalg}-$ формування файлів шаблонів.

Функціонально-компонентна модель використовується для представлення взаємодій, відношень і залежностей програмних модулів, а також для детального опису компонентів системи. Узагальнено дану модель для програмного комплексу трансдисциплінарного представлення геопросторової інформації можна представити структурою (30):

$$
S_{R}=<M_{D}, M_{S}, M_{P}, M_{C}, P_{0}\left(M_{D}, M_{S}\right)>
$$

Елементи, що входять в дану модель:

1) $M_{D}$ - модель, що задає поведінку системи;

2) $M_{S}$ - модель, що задає структуру системи;

3) $M_{P}$ - модель, що задає структуру програмних сутностей;

4) $M_{C}$ - модель (схема) компонентів програмної системи;

5) $P_{0}\left(M_{D}, M_{S}\right)$ - предикат цілісності системи.

Використання IТ-ТОДОС $є$ перспективним підходом для створення й застосування інформаційних технологій та систем для автоматизованої переробки та використання інформації мережевого середовища, яка, на відміну від відомих підходів до забезпечення інтегрованої взаємодії 3 інформаційними ресурсами, не лише враховує атрибутивні ознаки об'єктів предметної області прикладної задачі, а й забезпечує повномасштабне врахування усіх властивостей тематичних об'єктів, які використовуються при розв'язанні складних політематичних проблем та задач теорії управління.

Узагальнена схема трансдисциплінарного представлення мережевих інформаційних ресурсів за технологією ТОДОС представлена на рис. 3. 


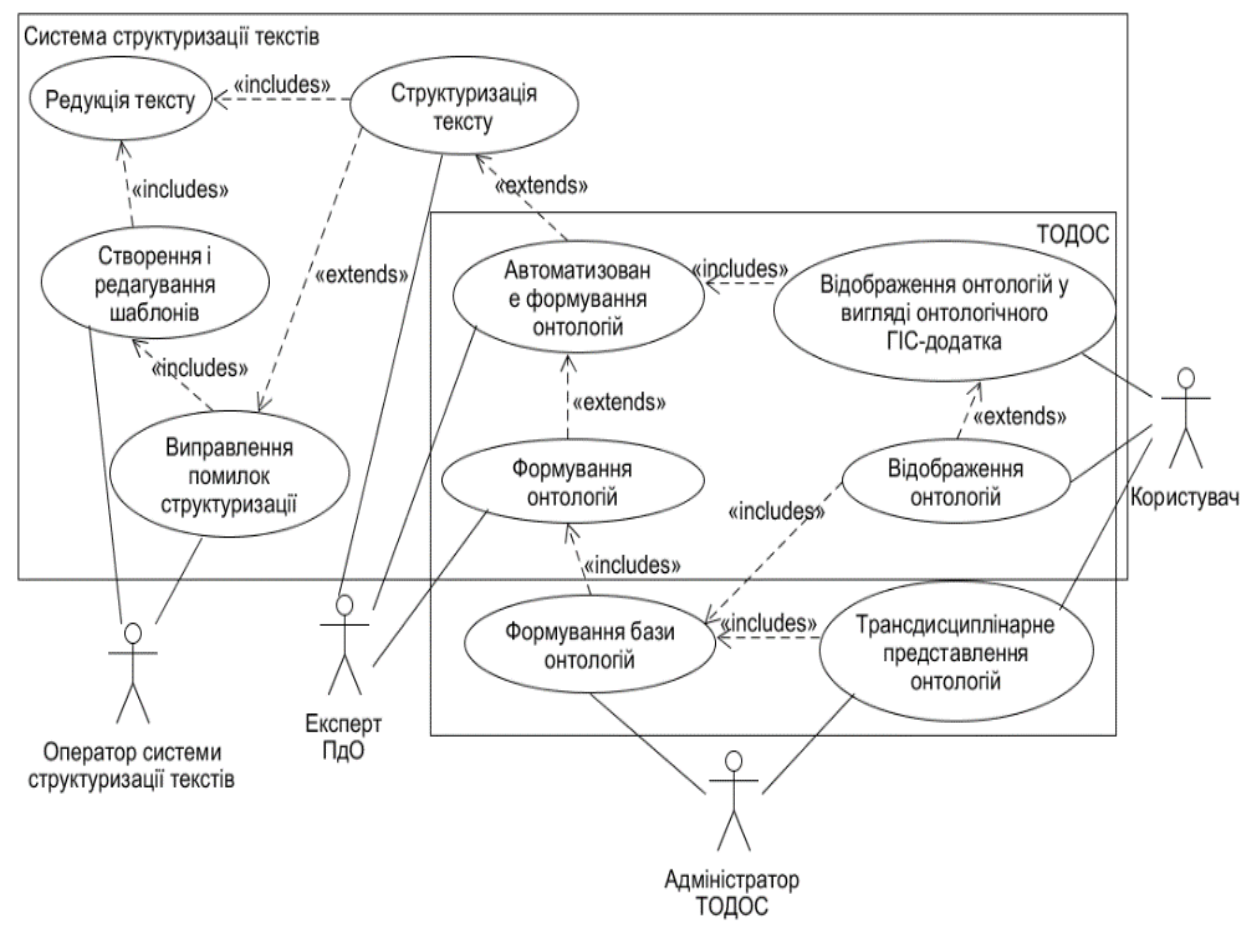

Рис. 3 - Узагальнена схема трансдисциплінарного представлення мережевих інформаційних ресурсів за технологією ТОДОС

\section{Висновки}

Дослідження проблем, пов'язаних з організацією ефективного управління на основі аналізу міждисциплінарних інформаційних ресурсів, показує, що існує необхідність розробки нових методів та засобів управління інформацією для забезпечення доступу до знань, їх об'єднання та формування нових знань. Гострота питання особливо відчувається у великих комплексних проектах, a також мультидисциплінарних i трансдисциплінарних дослідженнях, які полягають у розгляді того чи іншого явища поза рамками якоїсь однієї наукової дисципліни, що є найважливішим завданням для проектувальників $\mathrm{i}$ творців розподілених мережевих інформаційно-аналітичних систем підтримки прийняття рішень.

Представлені наукові, методологічні засади та технічні рішення побудови сучасних інформаційних технологій використання мережевих інформаційних ресурсів показали, що трансдисциплінарні рішення повністю дозволяють використовувати у довільному контурі управління саме політематичні інформаційні ресурси через множинність та невпорядкованість їх семантичних властивостей, а також нечіткість їх описів під час розв'язання складних прикладних задач міждисциплінарного характеру.

Трансдисциплінарність грунтується на зусиллях формального взаємозв'язку розумінь окремих дисциплін із формуванням логічних метарамок, за допомогою яких знання, що викладені в цих дисциплінах, можуть бути інтегровані на більш високому рівні абстракції, ніж це відбувається в міждисциплінарності. Тому один 3 вірних виборів методу 
вирішення задачі здобування та управління знаннями в міждисциплінарному інформаційному середовищі - використання методів інженерії знань, а саме використання онтологій на основі методології трансдисциплінарності.

Тому розв'язання задачі забезпечення трансдисциплінарних досліджень в міждисциплінарному інформаційному середовищі полягає в необхідності розробки засобів забезпечення загального трансдисциплінарного онтологічного представлення семантики, що надасть можливості зберігання, обробки та доступу до його різнорідних об'єктів та інформаційних одиниць.

Інтеграція міждисциплінарних ресурсів в єдиному онтолого-керованому середовищі також вирішується шляхом застосування трансдисциплінарного підходу.

Методологія трансдисциплінарності - це спосіб розуміння, пізнання і опису об'єкта у складі єдиного множинного упорядкованого середовища; спосіб управління станом об'єкта і природного середовища його існування.

\section{СПИСОК ЛІТЕРАТУРИ}

1. Довгий С.О. Системи підтримки прийняття рішень на основі статистичноймовірнісних методів [Текст] : (наук.-навч. вид.) / С.О. Довгий, П.І. Бідюк, О.М. Трофимчук ; Нац. акад. наук України, Ін-т телекомунікацій і глобал. інформ. простору. - Київ : Логос, 2014. - 419 с.

2. Інформаційно-аналітичне супроводження бюджетного процесу [Текст] : монографія / С.О. Довгий, І.В. Сергієнко, М.Ю. Авксєнтьєв [та ін.] ; за ред. С.О. Довгого, I.В. Сергієнка ; Нац. акад. наук України, Ін-т економіки та прогнозування [та ін.]. - Київ : Інформ. системи, 2013. - 420 с.

3. Поспелов Д.А. Ситуационное управление. Теория и практика / Д.А. Поспелов. - М. : Наука, 1986. - 284 с.

4. Ильин Н.И. Ситуационные центры. Опыт, состояние, тенденции развития / Н.И. Ильин, Н.Н. Демидов, Е. В. Новикова. - М. : Медиа Пресс, 2011. - 336 с.

5. Массель Л. В. Ситуационное управление и семантическое моделирование в энергетике / Л. В. Массель, А. Г. Массель // Открытые семантические технологии проектирования интеллектуальных систем = Open Semantic Technologies for Intelligent Systems (OSTIS-2014) : материалы IV междунар. науч.-техн. конф. (Минск, 20-22 февраля 2014 года) / редкол.: В. В. Голенков (отв. ред.) [и другие]. - Минск : БГУИР, 2014. - С. 111-116.

6. Основи системного аналізу [Текст] / М. З. Згуровський, Н. Д. Панкратова ; за заг. ред. акад. НАН України М. З. Згуровського. - Київ : Видавнича група ВНV, 2007. - 543 с.

7. Кунц Г., Донел С.О. Управление: системный и ситуационный анализ управленческих функций / Г. Кунц, С.О. Донел; пер. с англ.; под ред. Д.М. Гвишиани. - Т.1, II. - М. : Прогресс, 1991. - 250 с.

8. Стрижак О. Є. Трансдисциплінарна інтеграція інформаційних ресурсів [Текст] : автореф. дис. ... д-ра техн. наук : 05.13.06 / Стрижак Олександр Свгенійович ; Нац. акад. наук України, Ін-т телекомунікацій і глобал. інформ. простору. - Київ, 2014. $47 \mathrm{c}$.

9. Киященко Л. П. Философия трансдисциплинарности [Текст] / Киященко Л.П. Моисеев В.И.; Рос. акад. наук, Ин-т философии. - М. : ИФРАН, 2009. - 205 с.

10. Князева Е.Н. Трансдисциплинарные стратегии исследований [Текст] / Е.Н. Князева // Вестник ТГПУ, 2011. - №10. - С. 193-201.

11. Мокий М. С. Трансдисциплинарная методология в экономических исследованиях : автореф. дис. на соискание ученой степени д-ра эконом.наук : спец. 08.00.01 «Экономическая теория» / М. С. Мокий ; Российская Экономическая академия им. Г.В. Плеханова. - М., 2010 - 50 с. 
12. Klein J. Th. Transdisciplinarity: Joint Problem Solving Among Science, Technology, and Society: An Effective Way for Managing Complexity / Julie Thompson Klein. - Birkhäuser, 2001.

13. Transdisciplinarity: Basarab Nicolescu. Talks with Russ Volckmann, Integral Review Journal, 4, 2007. - P. 76.

14. Transdisciplinary Mind: An Interview with Ian Mitroff, by Russ Volckmann // Integral Review Journal, 2006, Vol.2. - P. 25-42.

15. Палагин А.В. Онтологические методы и средства обработки предметных знаний: моногр. / А.В. Палагин, С.Л. Крывый, Н.Г. Петренко. - Луганск: изд-во ВНУ им. В. Даля, 2012. - 323 с.

16. Гладун В.П. Процессы формирования новых знаний [Текст] / В.П. Гладун. - София : СД «Педагог 6», 1994. - 192 с.

17. Стрижак А. Е. Онтологические аспекты трансдисциплинарной интеграции информационных ресурсов / А. Е. Стрижак // Открытые информационные и компьютерные интегрированные технологии, 2014. - № 65. - С. 211-223.

18. Gonzales-Castillo J., Trastour D., and Bartolini C., "Description logics for matchmaking of services", In Proc. of Workshop on Application of Description Logics, 2001.

19. Guarino N. Understanding, Building, and Using Ontologies // URL: http://ksi.cpsc.ucalgary.ca/KAW/KAW96/guarino/guarino.html.

20. Добров Б. В. Онтологии и тезаурусы: модели, инструменты, приложения: учебное пособие / Б. В. Добров, В. В. Иванов, Н. В. Лукашевич, В. Д. Соловьев. - М. : ИнтернетУниверситет Информационных Технологий; БИНОМ. Лаборатория знаний. - 2009. 173 с. (Серия «Основы информационных технологий»).

21. Грей П. Логика, алгебра и базы данных [Текст] / П. Грей. - М. : Машиностроение, 1989. - 368 c.

22. Кантор Г. Труды по теории множеств. - Москва: Наука, 1985. - 436 с.

23. Клини С. К. Введение в метаматематику [Текст] / С. К. Клини. - М. : Иностранная литература, 1957. - $526 \mathrm{c.}$

24. Колмогоров А. Н., Драгалин А. Г. Математическая логика. - М. : УРСС, 2005. $240 \mathrm{c}$.

25. Малишевский А. В. Качественные модели в теории сложных систем. - М.: Наука. Физматлит. 1998. - 528 с.

26. Шаталкин А.И. Таксономия. Основания, принципы и правила [Текст] / А.И. Шаталкин. - М. : Товарищество научных изданий КМК, 2012. - 600 с.

27. Stryzhak O., Prychodniuk V., Podlipaiev V. (2019) Model of Transdisciplinary Representation of GEOspatial Information. In: Ilchenko M., Uryvsky L., Globa L. (eds) Advances in Information and Communication Technologies. UKRMICO 2018. Lecture Notes in Electrical Engineering, vol 560. Springer, Cham

28. Барендрегт Х. Ламбда-исчисление. Его синтаксис и семантика: Пер. с англ. - М. : Мир, 1985. -606 с.

29. Буч Г. Объектно-ориентированный анализ и проектирование с примерами приложений на С++ / Г. Буч; [пер. с англ. И. Романовского, Ф. Андреева]. - 1998. $359 \mathrm{c}$.

30. Величко В.Ю. Комплексные инструментальные средства инженерии онтологий / В.Ю. Величко, К.С. Малахов, В.В. Семенков, А.Е. Стрижак // International Journal «Information Models and Analyses», 2014. - Volume 3. - Number 4. - P. 336-361.

31.Приходнюк В.В. Технологічні засоби трансдисциплінарного представлення геопросторової інформації [Текст] : автореф. дис. ... к-та техн. наук : 05.13.06 / Приходнюк Віталій Валерійович; Нац. акад. наук України, Ін-т телекомунікацій і глобал. інформ. простору. - Київ, 2017. -20 с.

32. Приходнюк В.В. Таксономизация естественно-языковых текстов / Приходнюк В. // International Journal «Information Models and Analyses», 2016. - Volume 5. - Number 3. C. 270-284. 
33. Broy M. Mathematical Methods in System and Software Engineering. NATO ASI SERIES F COMPUTER AND SYSTEMS SCIENCES. Berlin : Springer, 1997. - №. 158. C. 271-312.

34. Broy M. Mathematical System Models as a Basis of Software Engineering. Berlin. 35. Melo F., Martins B. Automated Geocoding of Textual Documents: A Survey of Current Approaches. Transactions in GIS, 2017.

Стаття надійшла до редакиіï 20.05.2019 і прийнята до друку після рецензування 07.06.2019

\section{REFERENCES (TRANSLATED AND TRANSLITERATED)}

1. Dovgyj S.O., Bidjuk P.I., Trofymchuk O.M. (2014). Systemy pidtrymky pryjnjattja rishen' na osnovi statystychno-jmovirnisnyh metodiv [Decision support systems based on statistical probabilistic methods]. Kyi'v: Logos, 419 [in Ukraine].

2. Dovhyi S.O., Serhiienko I.V., Avksentiev M.Iu., Bihdan V.B., Horbachuk V.M., Huliaiev K.D., Hulianytskyi L.D., Karpets E.P., Kopiika O.V., Lebeda T.B., Sember S.V., Siverskyi P.M., Skrypnychenko M.I., Sokolyk M.P., Trofymchuk O.M., Chornyi Yu.M., Shumska S.S. (2013). Informacijno-analitychne suprovodzhennja bjudzhetnogo procesu [Information and analytical support of the budget process]. K.: TOV «Informacijni systemy», 420 [in Ukraine].

3. Pospelov D.A. (1986). Situatsionnoe upravlenie. Teoriya i praktika [Situational management. Theory and practice]. M.: Nauka, 284 [in Russian].

4. Il'in N.I., Demidov N.N., Novikova E. V. (2011). Situacionnye centry. Opyt, sostojanie, tendencii razvitija [Situation centers. Experience, state, development trends]. M.: Media Press, 336 [in Russian].

5. Massel' L.V. Massel' A.G. (2014). Situacionnoe upravlenie i semanticheskoe modelirovanie $\mathrm{v}$ jenergetike [Situational management and semantic modeling in the energy sector] Materialy Mezhdunarodnoj nauchno-tehnicheskoj konferencii (Minsk, 20-22 fevralja) [Proceedings of the International Scientific and Technical Conference (Minsk, February 20-22). pp. 111-116 [in Russian].

6. Zghurovs'kyj M.Z., Pankratova N.D. (2007). Osnovy systemnoho analizu [Fundamentals of system analysis]. K.: Vydavnycha hrupa BHV, 546 [in Ukraine].

7. Kunc G., Donel S. O. (1991). Upravlenie: sistemnyj i situacionnyj analiz upravlencheskih funkcij [Management: system and situational analysis of management functions]. Progress, T.1, II, 250 [in Russian].

8. Stryzhak O. Ye. (2014). Transdystsyplinarna intehratsiia informatsijnykh resursiv [Tekst] : avtoref. dys. ... d-ra tekhn. nauk : 05.13.06 / Stryzhak Oleksandr Yevhenijovych ; Nats. akad. nauk Ukrainy, In-t telekomunikatsij i hlobal. inform. prostoru [Strizhak O. E. Transdisciplinary integration of information resources [text]: author's abstract. dis ... Dr. tech. Sciences: 05.13.06 / Strizhak Alexander Evgenevich; National acad. Sciences of Ukraine, Institute of Telecommunications and Global. inform space]. Kyiv, 47 [in Ukraine].

9. Kyjashhenko L. P., Moyseev V. Y. (2009) Fylosofyja transdyscyplynarnosty [Transdisciplinarity Philosophy] Ros. akad. nauk, Yn-t fylosofyy [Russian Acad. Sciences, Institute of Philosophy]. M.: YFRAN [in Russian].

10. Knjazeva E. N. (2011). Transdisciplinarnye strategii issledovanij [Transdisciplinary Research Strategies] Vestnik TGPU [Tomsk State Pedagogical University Bulletin], 10, 193 201 [in Russian].

11. Mokij M. S. (2010). Transdisciplinarnaja metodologija $v$ jekonomicheskih issledovanijah : avtoref. dis. na soiskanie uchenoj stepeni d-ra jekonom. nauk : spec. 08.00.01 «Jekonomicheskaja teorija» [Transdisciplinary methodology in economic research: author. dis. for the degree of doctor of economical science: spec. 08.00.01 "Economic Theory"], 
Rossijskaja Jekonomicheskaja akademija im. G. V. Plehanova - M. Russian Academy of Economics. G.V. Plekhanov, 50 [in Russian].

12. Klein J. Th. (2001). Transdisciplinarity: Joint Problem Solving Among Science, Technology, and Society: An Effective Way for Managing Complexity - Birkhäuser.

13. Basarab Nicolescu (2007). Transdisciplinarity. Talks with Russ Volckmann. Integral Review Journal, 4, P.76.

14. Transdisciplinary Mind (2006): An Interview with Ian Mitroff, by Russ Volckmann. Integral Review Journal, Vol.2, P. 25-42.

15. Palagin A.V., Kryvyj S.L., Petrenko N.G. (2012). Ontologicheskie metody i sredstva obrabotki predmetnyh znanij: monogr. [Ontological methods and means of processing subject knowledge: monograph]. Lugansk: izd-vo VNU im. V. Dalja - Lugansk: publishing house of the National University of Ukraine. V. Dahl, 323 [in Russian].

16. Gladun V. P. (1994). Processy formirovanija novyh znanij [Processes of formation of new knowledge]. Sofija : SD «Pedagog 6»-Sofia: ST «Teacher 6», 192 [in Russian].

17. Strizhak A. E. (2014). Ontologicheskie aspekty transdisciplinarnoj integracii informacionnyh resursov [Ontological aspects of transdisciplinary integration of information resources]. Otkrytye informacionnye i komp'juternye integrirovannye tehnologii - Open information and computer integrated technologies, 65, 211-223 [in Russian].

18. Gonzales-Castillo J., Trastour D., \& Bartolini C. (2001). Description logics for matchmaking of services, In Proc. of Workshop on Application of Description Logics.

19. Guarino N. Understanding, Building, and Using Ontologies. Retrieved from: http://ksi.cpsc.ucalgary.ca/KAW/KAW96/guarino/guarino.html.

20. Dobrov B. V., Ivanov V. V., Lukashevich N. V., Solov'ev V. D. (2009). Ontologii i tezaurusy: modeli, instrumenty, prilozhenija: uchebnoe posobie [Ontologies and thesauri: models, tools, applications: a tutorial]. M. : Internet-Universitet Informacionnyh Tehnologij; BINOM. Laboratorija znanij. Serija «Osnovy informacionnyh tehnologij» - M.: Internet University of Information Technologies; BINOMIAL. Lab knowledge, A series of "Fundamentals of Information Technology", 173 [in Russian].

21. Grej P. (1989). Logika, algebra i bazy dannyh [Logic, algebra and database]. M. : Mashinostroenie - M.: Mechanical Engineering, 368 [in Russian].

22. Kantor G. (1985). Trudy po teorii mnozhestv [Works on set theory]. Moskva: Nauka Moscow: Science, 436 [in Russian].

23. Klini S. K. (1957). Vvedenie v metamatematiku [Introduction to metamathematics]. M. : Inostrannaja literatura - M.: Foreign literature, 526 [in Russian].

24. Kolmogorov A. N., Dragalin A. G. (2005). Matematicheskaja logika [Mathematical logic]. M.: URSS, 240 [in Russian].

25. Malishevskij A. V. (1998). Kachestvennye modeli v teorii slozhnyh system [Qualitative models in the theory of complex systems]. M.: Nauka. Fizmatlit - M. : Science. Fizmatlit, 528 [in Russian].

26. Shatalkin A. I. (2012). Taksonomija. Osnovanija, principy i pravila [Taxonomy. Grounds, principles and rules]. M. : Tovarishhestvo nauchnyh izdanij KMK - Fellowship of scientific publications KMK, 600 [in Russian].

27. Stryzhak O., Prychodniuk V., Podlipaiev V. (2019). Model of Transdisciplinary Representation of GEOspatial Information. In: Ilchenko M., Uryvsky L., Globa L. (eds) Advances in Information and Communication Technologies. UKRMICO 2018. Lecture Notes in Electrical Engineering, vol 560. Springer, Cham [in English].

28. Barendregt X. (1985). Lambda-ischislenie. Ego sintaksis i semantika [Lambda calculus. Its syntax and semantics]. Mir, 606 [in Russian].

29. Buch G. (1998). Ob'ektno-orientirovannyj analiz i proektirovanie s primerami prilozhenij na $\mathrm{C}++$ / per. s angl. I. Romanovskogo, F. Andreeva [Object-oriented analysis and design with examples of applications in $\mathrm{C}++$ / transl. from English I. Romanovsky, F. Andreeva], 359 [in Russian]. 
30. Velichko V. Ju., Malahov K. S., Semenkov V. V., Strizhak A. E. (2014). Kompleksnye instrumental'nye sredstva inzhenerii ontologij [Comprehensive ontology engineering tools]. International Journal «Information Models and Analyses», Vol. 3, № 4, 336-361.

31. Prihodnjuk V.V. (2017). Tehnologichni zasobi transdisciplinarnogo predstavlennja geoprostorovoï informaciï [Tekst] : avtoref. dis. ... k-ta tehn. nauk : 05.13.06 / Prihodnjuk Vitalij Valerijovich; Nac. akad. nauk Ukraïni, In-t telekomunikacij i global. inform. Prostoru [Technological means of transdisciplinary representation of geospatial information [Text]: author's abstract. dis ... to that tech. Sciences: 05.13.06 / Vitaly Valerievich Prihodnjuk; National acad. Sciences of Ukraine, Institute of Telecommunications and Global. inform space Kyiv, 20 [in Ukraine].

32. Prihodnjuk V.V. (2016). Taksonomizacija estestvenno-jazykovyh tekstov [Taxonomization of natural language texts]. International Journal «Information Models and Analyses», Volume 5, Number 3, 270-284 [in Russian].

33. Broy M. (1997). Mathematical Methods in System and Software Engineering. NATO ASI SERIES F COMPUTER AND SYSTEMS SCIENCES. Berlin : Springer, №. 158, 271312.

34. Broy M. Mathematical System Models as a Basis of Software Engineering. Berlin. 35. Melo F., Martins B. (2017). Automated Geocoding of Textual Documents: A Survey of Current Approaches. Transactions in GIS.

The article was received 20.05.2019 and was accepted after revision 07.06.2019

\section{Стрижак Олександр Євгенійович}

доктор технічних наук, старший науковий співробітник, головний науковий співробітник відділу онтологічних систем та прикладної алгебраїчної комбінаторики Інституту телекомунікацій і глобального інформаційного простору НАН України

Адреса робоча: 03186 Україна, м. Київ, Чоколівський бульвар, 13

e-mail: sae953@gmail.com

ORCID ID 0000-0002-4954-3650

\section{Потапов Григорій Михайлович}

кандидат технічних наук, старший науковий співробітник Інституту телекомунікацій $\mathrm{i}$ глобального інформаційного простору НАН України

Адреса робоча: 03186 Україна, м. Київ, Чоколівський бульвар, 13

e-mail:pgm201602@gmail.com

ORCID ID 0000-0002-5778-9327

\section{Приходнюк Віталій Валерійович}

кандидат технічних наук, молодший науковий співробітник Інституту телекомунікацій і глобального інформаційного простору НАН України

Адреса робоча: 03186 Україна, м. Київ, Чоколівський бульвар, 13

e-mail: tangens91@gmail.com

ORCID ID 0000-0002-2108-7091

\section{Чепков Роман Ігорович}

Радник директора з геоінформаційних питань Науково-дослідного інституту геодезії і картографії

Адреса робоча: 03150, Україна, м. Київ, вул. Велика Васильківська, 69

e-mail: chepkovroman@ukr.net

ORCID ID 0000-0003-2810-4576 